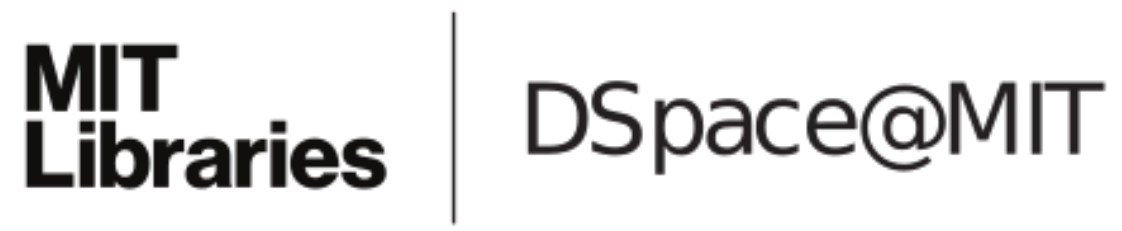

\author{
MIT Open Access Articles
}

Globalization Nationalized

The MIT Faculty has made this article openly available. Please share how this access benefits you. Your story matters.

Citation: Mazlish, Bruce (2009) "Globalization Nationalized," New Global Studies: Vol. 3 : Iss. 3 , Article 2. (c) 2009 Berkeley Electronic Press

As Published: http://dx.doi.org/10.2202/1940-0004.1085

Publisher: Berkeley Electronic Press

Persistent URL: http://hdl.handle.net/1721.1/61371

Version: Final published version: final published article, as it appeared in a journal, conference proceedings, or other formally published context

Terms of Use: Article is made available in accordance with the publisher's policy and may be subject to US copyright law. Please refer to the publisher's site for terms of use. 
New Global Studies

Volume 3, Issue $32009 \quad$ Article 2

Globalization Nationalized

Bruce Mazlish, Massachusetts Institute of Technology

Recommended Citation:

Mazlish, Bruce (2009) "Globalization Nationalized," New Global Studies: Vol. 3 : Iss. 3, Article 2.

Available at: http://www.bepress.com/ngs/vol3/iss3/art2

DOI: $10.2202 / 1940-0004.1085$

C2010 New Global Studies. All rights reserved. 


\title{
Globalization Nationalized
}

\author{
Bruce Mazlish
}

\begin{abstract}
Globalism and globalization have been seen as competitors to other allegiances, namely regionalism and nationalism. A look at recent efforts at reconceptualizing global history in China, Korea and the U.S., however, suggests that this competition is overdrawn, and that nationalist agendas in particular have found their way into global studies.
\end{abstract}

KEYWORDS: globalization, nationalism, Americanization, China, Korea, humanity 
For many social scientists, globalization is eroding the forces of nationalism. The latter is frequently seen as a consequence of modernity, with the processes of globalization,, especially during the last half century, now replacing modernity and its resultant nationalism. The literature on this subject has been growing, and is important. I myself have contributed to it in various places. It is not the aspect of the subject, however, to which I am devoting my attention here.

Rather, I wish to examine the way in which nationalism, in subtle and obvious ways, seeks to use globalization for its own purposes. It is a kind of "if you can't beat them, join them," although, in fact, it is a way of beating them by other means.

Now it is true that in the nineteenth century, voices were raised seeking to enlist national feeling in the course of a wider adherence to humanity. Thus the Italian patriot, Giuseppe Mazzini, spoke glowingly of his commitment to Italian nationalism and the emerging nation-state that it animated as part of his larger adherence to mankind. In this he was echoing the words of Goethe, extolling a cosmopolitan ethos, declaring that the aim of national feeling was "not uniformity...but mutual understanding and tolerance between nations through the

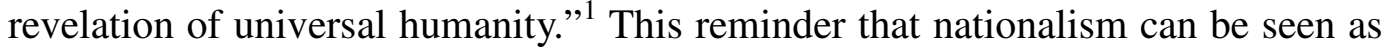
a form of social binding that is not incompatible with larger ties is important as we proceed with our inquiry.

With that said, let us look at some of what is happening as national aims wrap themselves in a seeming embrace of the global. A conference held at Harvard in 2008, "Global History Globally," illustrates this point exceptionally well. Papers on Korea, Turkey, Australia, China, the UK, Japan, and others show quite specifically how the appropriation of the global for national purposes is carried out. In an especially brilliant account of historiographic developments in Korea Jie-Hyun Lim argued persuasively that "various orientations of transnational history, once presumed as the alternative to competing national histories in East Asia, accommodated and even served nationalist agenda." (7)

The road leading to this development is itself transnational. It is Japan that mirrors the rise of European national histories, and in this mirror both pursues and narrates its own path to national history in the $19-20^{\text {th }}$ centuries. As Jie-Hyun Lim then informed us, Korean national history was "a product of a similar attempt, except with Japan in the place of 'West'." (3) Thus, there is a "global chain of national histories." (4) It is a subtle and complicated argument, in which transnationalism first serves the course of Japanese and Korean national histories, and then transmutes itself into global history while still serving the cause of national history.

\footnotetext{
${ }^{1}$ Daedalus, Summer 2008, back page.
} 
It should not surprise us that as globalization brings East Asian countries into closer relations, it also heightens national tensions. Indeed, this is true in regard to globalization all over the world and in regard to all polities. As nations are tied more closely to one another, such connections give rise to increased tension and a pull to difference and particularism. This is the constant tug of war between universalism and the local and relative. The examples of Japan and Korea bear out this generalization, where specifics can be found. It is in this context, and within varying local contexts, that transnational and now global history is subject to national appropriation.

My next example is The People's Republic of China. Repeatedly humiliated by Western and other powers in the nineteenth century, China turned to nationalism with Sun Yat-Sen and later Chiang Kai-Shek, then communism with Mao Tse-Tung, and into capitalism with Deng Xiaoping, while retaining socialist features and a Communist Party control apparatus. Into this mixed bag of "ties" holding the country together, efforts were also made to revive Confucian teachings and ideals and other "traditional" elements of China's heritage. It is into this mix, now occurring in a time of increased globalization, that the theme of nationalism persisted or was reawakened.

My personal entry into this problem occurred via an e-mail message from China. It informed me of the existence of a new journal, and asked if I would contribute something. The journal, published in Beijing, was called "Chinese Global History Review," and it was primarily concerned with world and global history, to which I added new global history (i.e., post-WW II globalization). My assignment was to write on all three "fields" or approaches.

The interest of Chinese historians in these subjects was obviously rooted in a desire to share in the efforts to escape Eurocentrism found in the West but mostly in the fact that China was now a significant player in the unfolding global processes. In my submission, I gave a good deal of attention to new global history, after comparing it to world and global history, and then commented that, "Now globalization is seen as an enterprise being undertaken by the whole of the human species; and requiring the attention of all peoples." In this oblique manner I was suggesting to Chinese historians that, like Mazzini a century earlier, they needed to serve both nationalistic aims and those of a larger humanity.

There is much in the Chinese heritage that lends itself to this larger purpose; and, indeed, I am optimistic that China will sooner or later move in this direction. My editor at the new journal, however, was troubled by my message and demurred at its inclusion. Global history at the moment was too important as a supporter in the cause of nationalism to be enlisted also in a larger human cause. Subsequently I have seen neither the translation of my article nor heard any further news of the journal. A finger in the wind (and which wind?), this small 
incident was another item in my consideration of enlisting globalization and its histories in the ranks of national history.

Support for this position comes from recognized scholars such as Q. Edward Wang, another participant in the Harvard conference. As he observed, after 1949, when the communists took power in China, "world history" became a legitimate field in historical study, basing itself on the Marxist vision. (16) This was not the case with the nationalists who had retreated to Taiwan. As for the mainland Chinese world historians, one obvious desire was to compare their status with the "advanced" societies of the West. In fact, as Wang tells us, a "Research Center for Global History" was established in 2004, headed by Liu Xincheng, a historian of early modern Europe who also recently became his university's president. Under the guidance of Liu and his colleagues, a dozen or so Chinese students are currently working on their master's and doctoral degrees, hoping to become 'global historians'." (19) In these developments, we can also see the presence of national aspirations.

The new Center is at Capital Normal University, and it is strongly connected to the Journal of World History, and its editor Jerry Bentley. The JWH is a font of considerations on world history, with much attention to China and its entry into the field. A typical recent article is Luo $\mathrm{Xu}$, "Reconstructing World History in the People's Republic of China since the 1980s," which details the various barriers to the effort "to envision a world history with Chinese characteristics." 2 Other articles by Q. Edward Wang can also be found there. Summing up much of this work, Wang concludes that each attempt at global history also invariably derives from and is circumscribed by a "localized concern and even a nationalist interest." (28)

What if we turn from China to the USA? Here we have both a flourishing discipline of history much concerned with world and global history and a country seen by many as the epitome of an embrace of globalization. Looked at more closely, however, we see that in this vein globalization is equated with the spread of the free market, American style, and in favor of American interests. Until the financial debacle of the recent months, this sort of globalization was applauded in spite of its unevenness and its harmful aspects as it impinged on many peoples and aspects of the economy. While obviously the economic was and is one part of the contemporary globalization process, its uncritical embrace was more ideological and reductionist than the result of careful examination and judicious understanding. Such simplicity, needless to say, served the purposes of American nationalism. To look at globalization whole is to see that the political, cultural, technological, and similar aspects of actual social life surround the economic and qualify its simple-minded "free" existence.

\footnotetext{
${ }^{2}$ September 2007, ii.
} 
Back in the 1940s and '50s, the role of the USA in international affairs seemed also to foster the global aspect. Instrumental in the establishment of the UN and its pursuit of the four freedoms, and especially of the Universal Declaration of Human Rights, presaging a new era in substituting or supplementing human concerns for national sovereignty, this direction was quickly aborted when America began to realize that it could not control the agenda of the world community when its impulses went beyond America's national interests. Increasingly, as this became evident, the US became hostile to the UN. This was shockingly obvious in the post-Reagan years when, with the Cold War finally over, and the other nations of the world seeking to steer relatively independent courses, the rise of the Bush administration made its intentions clear in the new National Security Doctrine. As in the Iraq invasion, America would act unilaterally when necessary in the name of its interests.

These interests were no longer coincident with those of an emerging global civil society, but those of a highly nationalistic USA. With its idealistic veneer, expressing a thin strip of American reality, it is often overlooked exactly how nationalistic the country is. Poll after poll showing this fact is frequently overlooked-America is home to one of the most nationalistic of peoples-and the abundant history underpinning its nationalist inclinations (partly hidden by the form of empire in which it exists) simply obscures the reality. And America's constant self-laudation as the benevolent and supportive leader in foreign aid and humanitarian efforts is dust in the eye of reality. Of course, there is a certain amount of reality; enough to obscure the fact that the USA, like Korea and China, has nationalist aims as it embraces various features of globalization.

Does such nationalism extend to its world and global historians? Interestingly, the conference on Global History Globally did not have a paper devoted to the subject in the US comparable to those on other parts of the globe, such as Korea, Japan, China, etc. To attempt such a study might require a conference similar in size. An equally needed conference is one on American hypocrisy. It is not that other nations do not also speak and act in hypocritical terms; it is the American air of innocence. Over the decades we have not only baffled our friends but ourselves in the process.

World and Global History promises to redeem some of this complacency. At its best moments, it does. But, as many critics have pointed out, its practitioners in America are still mostly Eurocentric. This tendency is abetted by methodological nationalism, or the fact that most archives and collections of statistics are organized along nation state lines. Further, many still see, consciously or unconsciously, globalization as a form of Americanization. Needless to say, recent financial events have weakened this confidence. A closely aligned form is to equate globalization with the free market; this, too, has been a badly shaken faith recently. A vacuum of belief has been created, which global 
historians can fill with a holistic approach, which demotes the economic factor from its position of primacy and partners it with the political, social, cultural, and so forth with which it always actually exists. Real historical analysis can and should take over from ideology.

With the nationalist inclinations of American historians admitted, it must be added that many do seek a transnational perspective that is truly such. It may be that such historians are further along the curve of realizing that to existing national ties and interests must increasingly be added those of humanity at large, partly because the US plays such a major role in creating the global problems that cry out for global solutions: climate, energy, military, political all bear the large footprint of Uncle Sam. The historians engaged in the truly transnational are ahead of their government-or perhaps out of sync-but hopefully are pointing the way. Or it may be that intellectuals tend to be disregarded, or disparaged by the general US democracy and the powers that be. Or that the latter are satisfied by the unreflective nationalism of those who, like historians in Korea, Japan, and China, for example, write global history in a fashion that serves the nationalist agenda.

This last is a very natural development. In the last three centuries or so, the national ties became an important source of identity and connections for many people. It became the social bond par excellence, either in practice or theory. It offers additional support to links rooted in family, tribe, and regional bindings. Now, as global historians are recognizing, the national interest is increasingly tied to the global. To be a good subject of the national polity means also being a good global subject. This realization is slowly creeping into the public perception, and partly inspired by and reflected in the writings of global historians. To go further along this route, all world and global historians have to constantly keep in mind the entity of humanity in their accounts.

To truly rise above the nationalist tendency, while paying it due accord, the historian needs to constantly add the perspective of humanity. What has been the effect on humanity of, say, the American purchase of Louisiana, as well as on the expansion of the original colonies? Of Andrew Jackson's Presidency? Of the British wars with Napoleon, i.e., not only in terms of the formation of the British empire but the cause of humanity? Similar questions must be raised in all other histories: Chinese, Indian, and so forth. And these considerations must be taken into account systematically and constantly and not just occasionally and by indirection.

Elsewhere I have argued that via the notion of crimes against humanity, in the post-WW II period, the concept of Humanity emerged. This has been the result of both globalization and a juridical revolution, culminating for the moment in the International Criminal Court. The concept's emergence is rooted in the 
earlier phases of globalization, but takes on "body" in the last half-century or so. ${ }^{3}$ Thus there is a guide to help us as we look back over episodes in World History and Global History accounts, seeking ways to avoid simply listing them unreflectively in the cause of national histories.

Even without such measures, a caution such as the present article may alert us to hidden dangers and put us on our guard as we pursue our work in World and Global History. This holds for all time periods and all areas. I have instanced Korea, China and the USA. The rest of the world and its histories can be added to this list. A World and Global History true to itself can do no less.

3 J.M. Headley, The Europeanization of the World: On the Origins of Human Rights and Democracy. (Princeton University Press, 2007); Bruce Mazlish, The Idea of Humanity in a Global Era. (Palgrave, 2008). 